\title{
PHYSIOLOGICAL EFFECT OF NITROGENOUS FERTILIZER, APPLICATION TIMES, AND POLYMER GEL ON THE GROWTH CHARACTERISTICS OF BREAD WHEAT Triticum aestivum $\mathrm{L}$.
}

\author{
Saleh M. I. Al-Jobouri ${ }^{1} \quad$ Amjad Th. Kh. Alabar ${ }^{2}$ \\ College of Agriculture and Forestry, University of Mosul -Iraq . Field Crops Dept. ${ }^{(1)}$ \\ Plant Production Dept . Agriculture Directorate Nineveh . Ministry of Agriculture. \\ Iraq ${ }^{(2)}$ \\ E:mail Salhmcbraheem@Yahoo.com
}

\begin{abstract}
A field experiment was carried out during the winter agricultural season 2019-2020 at two location (Al-Hamdaniya, Talkef) to study the effect of nitrogen fertilizer, its application dates, and polymer gel on the growth traits of bread wheat (Triticum aestivum L), cultivar Talafar (3), and the RCBD was used. According to the split plots system and with three replications, the experiment included two factors, the first factor, levels of nitrogen fertilizer and its addition times, which are five levels : $\{$ (zero as control treatment), (40 kg N $/ \mathrm{h}: 1 / 2$ when planting $+1 / 2$ beginning of Tillars), $(40 \mathrm{~kg} \mathrm{~N}$ /h: $1 / 3$ when planting $+2 / 3$ beginning of Tillars), $(80 \mathrm{kgN} / \mathrm{h}: 1 / 2$ when planting $+1 / 2$ beginning of Tillars), ( $80 \mathrm{~kg} \mathrm{~N} / \mathrm{h}: 1 / 3$ when planting $+2 / 3$ beginning of Tillars $)\}$ and the second factor polymer gel in four levels $(0,80,160$ and $240 \mathrm{~kg} / \mathrm{h})$ occupied coefficients The nitrogen fertilizer and the application of the main plots in the main plots experiment. The polymer gel levels occupied the sub plots. The results indicate that the levels of nitrogen fertilizer and the dates of its addition achieved a significant increase in most of the growth traits and for both locations, and the levels of polymer gel led to a significant increase in most of the growth traits, two study location, and The significant interaction response got all the growth traits except for the number of days until the beginning of flowering for the AL-Hamdaniya location and C.G.R for the Talkef location.
\end{abstract}

Keywords : application time, nitrogen fertilization, polymer gel ,wheat Received: 17 /11/ 2020, Accepted:18/2 /2021

\section{INTRODUCTION}

Wheat cultivation Triticum aestivum L. occupies strategic importance in global markets, and this is what prompted many developing and developed countries to adopt economic policies aimed at developing the crop and reducing its import with the aim of achieving sufficiency, and this means that countries seek to raise their competitiveness of this crop and boost their exports. And the development of its security sources of cash (Jassim, 2018). The area planted with wheat harvest for the 2019 season was 6331116 dunums and the productivity was estimated at 4343473 tons and the average yield was 686.11 $\mathrm{kg} / \mathrm{d}$ for Iraq in in important factors that lead to an increase in the yield and must be added in the general, and the area cultivated in Nineveh governorate was 1613187 dunums the soil and in the quantities that the plant needs is necessary to obtain good yield (Muhammad et al., 2016). Nitrogen fertilizers are considered one of the 
and its productivity was estimated at 851219 tons (Agricultural Statistics, 2019), Nitrogen is at the forefront of the nutrients that the plant needs, so its presence specified quantities and the dates recommended by the Ministry of Agriculture (Agricultural Research Center , 2014) polymer gel are hydrophobic polymers that can absorb large amounts of water as well as reduce hydration Artemisia nutrients on soil layers that the use of polymer gel may significantly reduce the effect of drought stress on the plant. Nevertheless, its use in field cultivation of field crops is little or very little , but with the recent decrease in the price of polymer gel significantly, it was the reason behind its use on crops, especially plants Wheat (Wyzinske and Grabinski, 2018), this research aims to test the best level of nitrogen fertilizer and application dates, as well as to test the technique of adding polymer gel to the soil and determine the appropriate level to obtain the best growth of bread wheat crops that are always cultivated in Moderate Rainfall area.

\section{MATERIALS AND METHODS}

Afield experiment was conducted in two location for the winter agricultural season 2019-2020 as the first experiment was applied in the fields of a farmer in the Jleiukhan area of AL-Hamdaniya district, which is a semi-guaranteed area of rain, which is $15 \mathrm{~km}$ from the center of the city of Mosul, and the other is in the fields of one of the farmers in the Talkef region. It is $20 \mathrm{~km}$ away from the city center of Mosul, which is a semi-guaranteed area of rain to study the effect of nitrogen fertilizer, its addition times, and polymer gel on the growth traits of the bread wheat crop (Triticum aestivum L) the experiment was carried out using the RCBD design according to the split plots system as reported by( Al-Rawi and Khalaf Allah , 2000) and with three replications, and each repeater consists of (20) experimental units and each experimental unit consists of 5 lines with a length of $(5 \mathrm{~m})$. And a distance of $(17 \mathrm{~cm})$ between one line and another, and the distance between an experimental unit and another $(1 \mathrm{~m})$ and between a repeater and another $(1 \mathrm{~m})$. and polymer gel was applied with the date of the first addition of nitrogen fertilizer and the entire phosphate fertilizer of $90 \mathrm{~kg} / \mathrm{h}\left(46 \% \mathrm{P}_{2} \mathrm{O}_{5}\right)$ when planting and at a depth of $(9 \mathrm{~cm})$ and a depth of $(5 \mathrm{~cm})$ respectively and the planting date was on 15/11/2019 for AL- Hamdaniya location and on 18/11/2019 Talkef location The study factors were as follows The first factor: the levels of nitrogen fertilizer and its application times, which are five levels including :

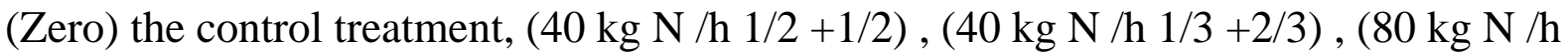
$1 / 2+1 / 2),(80 \mathrm{Kg} \mathrm{N} / \mathrm{h} 1 / 3+2 / 3)$ Note that the dates of addition include half the quantity when planting and the other half, the beginning of the tillers stage (Khalil et.al, 2015) The second factor: polymer gel with four levels $(0,80,160$ and $240 \mathrm{~kg} / \mathrm{h})$ occupied the levels of nitrogen fertilization and the dates of adding it to the main plots and the polymer gel levels occupied the sub plots. A sample was taken from different soil locations for each experiment at a depth of $(0-30 \mathrm{~cm})$ before planting and analyzed in the Department of Environmental Protection and Improvement/ Dohuk Environment / Laboratories Division. To determine the chemical and physical characteristics based on( Black ,1965) and the results of the analysis are shown in Table (1). Monthly rainfall rates were recorded during the agricultural season, in Al-Hamdania and Talkef for the year 2019-2020 Table (2) 
Table (1): Results of soil samples analysis.

\begin{tabular}{|c|c|c|c|c|c|c|c|c|c|c|}
\hline $\begin{array}{c}\text { The type of } \\
\text { sample }\end{array}$ & $\begin{array}{c}\text { Clay } \\
\%\end{array}$ & silt \% & $\begin{array}{c}\text { Sand } \\
\%\end{array}$ & Textural & $\begin{array}{c}\text { Total } \\
\text { nitrogen } \\
\text { ppm } \\
\end{array}$ & $\begin{array}{c}\text { Total } \\
\text { phosphorous } \\
\text { ppm }\end{array}$ & $\begin{array}{c}\text { Total } \\
\text { potassium } \\
\text { ppm }\end{array}$ & $\begin{array}{c}\text { organic } \\
\text { matter } \\
\%\end{array}$ & $\mathrm{PH}$ & $\begin{array}{l}\text { EC } \\
) \mathrm{dc} / \\
\mathrm{m}(\end{array}$ \\
\hline $\begin{array}{c}\text { AL- } \\
\text { Hamdaniya }\end{array}$ & 55.80 & 36.40 & 7.80 & $\begin{array}{l}\text { Silty } \\
\text { clay }\end{array}$ & 330 & 35.48 & 325 & 1.32 & 7.8 & $\begin{array}{c}0.16 \\
8\end{array}$ \\
\hline Talkef & 20.30 & 45.20 & 34.50 & Mix & 670 & 48.07 & 260 & 1.22 & 7.3 & $\begin{array}{c}0.26 \\
8\end{array}$ \\
\hline
\end{tabular}

Table (2): Monthly precipitation, rainfall amounts (mm).

\begin{tabular}{|c|c|c|c|c|c|c|c|c|c|}
\hline Month-year & $\begin{array}{c}\text { October } \\
\text { (1) } 2019\end{array}$ & $\begin{array}{c}\text { November } \\
\text { (2) } 2019\end{array}$ & $\begin{array}{c}\text { December } \\
2019\end{array}$ & $\begin{array}{c}\text { January } \\
2020\end{array}$ & $\begin{array}{c}\text { February } \\
2020\end{array}$ & $\begin{array}{c}\text { March } \\
2020\end{array}$ & $\begin{array}{c}\text { April } \\
2020\end{array}$ & $\begin{array}{c}\text { May } \\
2020\end{array}$ & Total /mm \\
\hline $\begin{array}{c}\text { AL- } \\
\text { Hamdaniya }\end{array}$ & 16 & 5 & 102 & 74 & 144 & 28 & 28 & 0 & 397 \\
\hline Talkef & 13 & 3 & 130.5 & 98 & 225 & 31.5 & 0 & 0 & 532.5 \\
\hline
\end{tabular}

The following traits were studied: The number of days until the beginning of flowering (Alamy ,2015), Plant height $(\mathrm{cm})$, The total number of tillers $\left(\mathrm{m}^{2}\right)$, The leaf area of the plant $\left(\mathrm{cm}^{2} \cdot \mathrm{m}^{-2}\right)$ Thomas ,1975), leaf area index , leaf area of the flag $\left(\mathrm{cm}^{2}\right)$ ,Chlorophyll Content Index (CCI) spad, Measuring the water content \% of the flag leaf when flowering ,Net Assimilation Rate(N.A.R).(g/ $/ \mathrm{cm}^{2} /$ day),Crop Growth Rate(C.G.R)(Hunt,1982 ).

The data for the studied traits were analyzed statistically using the SAS program, (Antar and Al-Wakaa, 2017) by Randomized complete block design ( RCBD) with the split plots system for each site separately, as reported by (Al-Rawi and Khalaf Allah, 2000). The coefficients for each of the sources of variance with the significant effect (Duncan, 1955). The averages followed by different letters indicate the existence of significant differences between them .

\section{RESULTS AND DISCUSSION}

The results presented in the Table $(3,4,5,6)$ indicated the response of most of the growth traits to the levels of nitrogen fertilizer, the dates of its addition and the polymer gel, as well as there was an interaction between the levels of nitrogen fertilizer and the dates of its addition with the levels of polymer gel in most of the growth traits. 1-The effect of fertilizer levels and application times on growth traits locations (AlHamdaniya and Talkef) two

The results presented in Table (3) indicate that the level of nitrogen fertilizer exceeded $80 \mathrm{~kg} \mathrm{~N} / \mathrm{h}$ and the date of the second addition was significant in all growth traits with the exception of the number of days until the beginning of flowering, which reached $111.66 \mathrm{~cm}, 368.17$ tiller. $\mathrm{m}^{2}, 35791 \mathrm{~cm}^{2} . \mathrm{m}^{2}, 3.57,25.45 \mathrm{~cm}^{2}, 16.03 \mathrm{CCI}, 65.77$ $\%, 0.0027700 \mathrm{~g} . \mathrm{cm}^{2} /$ day, $0.0099112 \mathrm{~g} . \mathrm{cm}^{2}$.day. for traits of plant height, number of tillers, leaf area, leaf area index, flag leaf area, CCI, water content \% of flag leaf,N,A.R and C.G.R respectively and did not differ significantly from the date of the first addition to the same level of fertilizer at AL- Hamdaniya location, and in Talkef location of this condition exceeds the level of nitrogen fertilizer $80 \mathrm{~kg} \mathrm{~N} / \mathrm{h}$ and the second addition date is significant in the quality of the number of days until the beginning of flowering, plant 
height, number of tillers $\mathrm{m}^{2}$, leaf area, leaf area index, flag leaf area and chlorophyll content index as it reached $125.7,113.58 \mathrm{~cm}, 556.75$ tiller.m ${ }^{2}, 65241 \mathrm{~cm}^{2} . \mathrm{m}^{2}, 6.50,36.72$ $\mathrm{cm}^{2}, 15.54 \mathrm{CCI}$. The reason for this is due to the date of adding the nitrogen element at the beginning of the branching stage, which is the growth stage during which the formation and growth of the various plant organs will lead to an increase in the ability to tillers out as a result of the increase in the meristematic activity of the plant (AbdulJawad et al. 1989) and it did not differ significantly from the date of the first addition of the same level of fertilizer. As for the traits of the water content \% of the flag leaf, net assimilation rate and crop growth rate, the fertilizer did not have a significant effect for these traits

2-The effect of the polymer gel levels on growth traits two locations.

The results presented in Table (4) show that there is a significant superiority between the levels of polymer gel for the growth traits in the two research locations. In AL- Hamdaniya location, the level of the polymer gel exceeded $160 \mathrm{~kg} / \mathrm{h}$ significantly in the traits of plant height, number of tillers, leaf area, leaf area index , net assimilation rate. The crop growth rate was $106.13 \mathrm{~cm}, 337.80$,tiller.m ${ }^{2}, 30336 \mathrm{~cm}^{2} . \mathrm{m}^{2}, 2.96$, $0.0029327 \mathrm{~g} . \mathrm{cm}^{2}$.day, $0.0085845 \mathrm{~g} . \mathrm{cm}^{2}$.day Respectively. It did not differ significantly from the level of the polymer gel $240 \mathrm{~kg} / \mathrm{h}$, while all the levels of the polymer gel were superior to the control treatment in the area of the flag leaf, chlorophyll content index and water content flag leaf. At the Talkef location, the level of $160,240 \mathrm{~kg} / \mathrm{h}$ was significantly higher in the quality of plant height, the number of tillers. $\mathrm{m}^{2}$ and water content $\%$ of the flag leaf, and the level $80,160,240 \mathrm{~kg} / \mathrm{h}$ was significantly higher than the control treatment in the traits of the leaf area, leaf area index, leaf area of the flag, chlorophyll content index and crop growth rate. The reason for this is that polymer gel led to the retention of water and nutrients and its provision to the plant during its growth stages and according to the plant's need, ie the polymer gel acted as a storage of moisture and nutrients (Jion et al., 2017) (EL-Hardy et al, 2009)As for the traits of the number of days until the beginning of flowering and the of crop growth rate, there were no significant differences between the levels of polymer gel for these traits

3- The effect of the interaction between nitrogen fertilizer, application dates and polymer gel on the growth traits of AL- Hamdaniya location.

Table (5) indicates the presence of an interaction between the nitrogen fertilizer, its application times, with polymer gel for all growth traits The interaction between the level of nitrogen fertilizer $40 \mathrm{~kg} \mathrm{~N} / \mathrm{h}$ with the date of the first addition with (zero) polymer gel gave the significant average of the number of days until the beginning of flowering reached 125.3, also the fertilizer level $80 \mathrm{~kg} \mathrm{~N} / \mathrm{h}$ and the date of the second addition with the level of polymer gel $160 \mathrm{~kg} / \mathrm{h}$ significant The average traits of the plant height was $113.66 \mathrm{~cm}$, the level was achieved at interaction $80 \mathrm{~kg} \mathrm{~N} / \mathrm{h}$, with the first time of addition with the level was $240 \mathrm{~kg} / \mathrm{h}$. interaction Level $160 \mathrm{~kg}$ of polymer gel /h with level $80 \mathrm{~kg} \mathrm{~N} / \mathrm{h}$, date of second edition with level $240 \mathrm{~kg}$ polymer gel $/ \mathrm{h}$, the significant rate of leaf area traits was $39289,38125 \mathrm{~cm}^{2} / \mathrm{m}^{2}$, the interaction between the level of $80 \mathrm{~kg} \mathrm{~N} / \mathrm{h}$ with the second addition date with the level $240 \mathrm{~kg}$ polymer gel $/ \mathrm{h}$ The highest average for leaf area index characteristic was 3.81, the level was given to $80 \mathrm{~kg} \mathrm{~N} / \mathrm{h}$ and the second addition date with polymer gel level $160 \mathrm{~kg} / \mathrm{h}$ The significant average for flag leaf area traits was $30.40 \mathrm{~cm}^{2}$, the interaction between the $80 \mathrm{~kg} \mathrm{~N} / \mathrm{h}$ level for the second appointment with the 80 level was achieved. $\mathrm{Kg} / \mathrm{h}$ 
polymer gel, the rate of traits The chlorophyll content index reached 16.87 spad, the interaction between the fertilizer level $80 \mathrm{~kg} \mathrm{~N} / \mathrm{h}$ with the first addition time with the level of $240 \mathrm{~kg}$ polymer gel $/ \mathrm{h}$, the highest rate of water content traits of the flag leaf was $75.60 \%$, the interaction between the level of the nitrogen fertilizer $80 \mathrm{~kg} \mathrm{~N} / \mathrm{h}$ with the first addition date With polymer gel level of $160 \mathrm{~kg} / \mathrm{h}$ for net assimilation rate traits, it reached $0.0033980 \mathrm{~g} / \mathrm{cm}^{2} / \mathrm{day}$, and it gave the significant rate of the traits between the level of nitrogen fertilizer $80 \mathrm{~kg} \mathrm{~N} / \mathrm{h}$ with the first time of addition with the level of polymer gel $160 \mathrm{~kg} / \mathrm{h}$, which reached $0.011758 \mathrm{~g} / \mathrm{cm}^{2} /$ day

4- The effect of the interaction between nitrogen fertilizer, application dates and polymer gel on the growth traits of Talkef location.

Table (6) indicates the presence of an interaction between the nitrogen fertilizer, its addition times, with the polymer gel for all growth traits except for N.A.R. traits, as it gave the interaction between the level of $80 \mathrm{~kg} \mathrm{~N} / \mathrm{h}$ with the first addition date with level 0,240 of the polymer gel, as well as the level $80 \mathrm{~kg} / \mathrm{h}$ with the second addition date with polymer gel level of $0,80 \mathrm{~kg} / \mathrm{h}$, the significant average of the grade was 126.3, 126.0,126.3, and 126.0, respectively. The interaction between the level of nitrogen fertilizer $80 \mathrm{~kg} \mathrm{~N} / \mathrm{h}$ with the date of first addition with the polymer gel $240 \mathrm{~kg}$ / h gave the significant rate plant height reached $118.33 \mathrm{~cm}$, it gave the level $80 \mathrm{~kg} \mathrm{~N}$ $/ \mathrm{h}$ with the date of the second addition with the level of polymer gel $240 \mathrm{~kg} / \mathrm{h}$ The significant rate of the number of tillers reached 594.67 tillers. $\mathrm{m}^{2}$, the rate of leaf area traits which reached $84560 \mathrm{~cm}^{2} \cdot \mathrm{m}^{2}$ of interaction between the level $80 \mathrm{~kg} \mathrm{~N} / \mathrm{h}$ and the date of the first addition with the level of $160 \mathrm{~kg}$ polymer gel $/ \mathrm{h}$, and the rate of the leaf area index trait was 7.93 from the interaction between the fertilizer level $80 \mathrm{~kg} \mathrm{~N} / \mathrm{h}$ and the date of the first addition with the level of polymer gel $160 \mathrm{~kg} / \mathrm{h}$, while the rate of the traits was reached Flag leaf area $42.66 \mathrm{~cm}^{2}$, gave interaction between the level of $80 \mathrm{~kg} / \mathrm{h}$ with the second dates of addition with the level of polymer gel of $240 \mathrm{~kg} / \mathrm{h}$ gave the interaction between the level of $80 \mathrm{~kg} \mathrm{~N} / \mathrm{h}$ the second date with the levels of polymers gel 160 and $240 \mathrm{~kg} / \mathrm{h}$, The significant average chlorophyll content index traits was 15.91 and 16.03 for the two levels respectively, The highest rate of water content $\%$ traits of the flag leaf was $82.45 \%$ of the interaction between the level of nitrogen fertilizer $40 \mathrm{~kg} \mathrm{~N} / \mathrm{h}$, the first date with the level of polymer gel $240 \mathrm{~kg} / \mathrm{h}$, gave the interaction between the fertilizer level $40 \mathrm{~kg} \mathrm{~N} / \mathrm{h}$ and the second addition date with the level of polymer gel $240 \mathrm{~kg} / \mathrm{h}$ and The The highest value for the traits of the crop growth rate was $0.016028 \mathrm{gm} / \mathrm{cm} /$ day. 
Mesopotamia J. of Agric.

Vol. (49) No. (1) 2021
ISSN: 2224 - 9796 (Online) ISSN: 1815 - 316 X (Print)

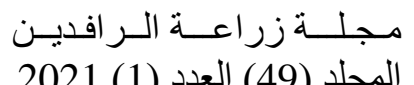

المجلد (49) العدد (1) 2021

Table (3): the effect of nitrogen fertilizer and application times on the growth traits of the two experimental location (Hamdaniya and

Talkef) AL- Hamdaniya location.

\begin{tabular}{|c|c|c|c|c|c|c|c|c|c|c|}
\hline $\begin{array}{l}\text { Frowth traits } \\
\text { and dates of } \\
\text { addition }(\mathrm{kg} / \mathrm{h})\end{array}$ & $\begin{array}{l}\text { No. days } \\
\text { until the } \\
\text { beginning of } \\
\text { flowering }\end{array}$ & $\begin{array}{l}\text { Plant } \\
\text { height } \\
(\mathrm{cm})\end{array}$ & $\begin{array}{l}\text { No. tillers } \\
\quad\left(\mathrm{m}^{2)}\right)\end{array}$ & $\begin{array}{l}\text { leaf area } \\
\left(\mathrm{cm}^{2} \cdot \mathrm{m}^{-2}\right)\end{array}$ & $\begin{array}{l}\text { leaf } \\
\text { area } \\
\text { index } \\
\left(\mathrm{cm}^{2}\right)\end{array}$ & $\begin{array}{l}\text { Flag leaf } \\
\text { area } \\
\left(\mathrm{cm}^{2}\right)\end{array}$ & $\begin{array}{l}\text { (CCI) } \\
\text { Spad }\end{array}$ & $\begin{array}{l}\text { Water } \\
\text { content } \% \\
\text { of flag } \\
\text { leaf }\end{array}$ & $\begin{array}{l}\text { (N.A.R }) \\
\left(\mathrm{g} / \mathrm{cm}^{2} /\right. \\
\text { day })\end{array}$ & $\begin{array}{c}\text { C.G.R } \\
\mathrm{g} / \mathrm{cm}^{2} / \text { day }\end{array}$ \\
\hline Zero & 124.0 & $100.25 \mathrm{c}$ & $297.33 \mathrm{c}$ & $20952 \mathrm{~b}$ & $2.08 \mathrm{c}$ & $16,81 \mathrm{c}$ & $13.03 \mathrm{~b}$ & $61.61 \mathrm{~b}$ & $0.0023 \mathrm{~b}$ & $0.0074 \mathrm{~d}$ \\
\hline $40(1 / 2+1 / 2)$ & 124.3 & $101.41 \mathrm{c}$ & $312.08 \mathrm{~b}$ & $23242 b$ & $\begin{array}{c}2.31 \mathrm{~b} \\
\mathrm{c}\end{array}$ & $19.00 \mathrm{~b} \mathrm{c}$ & $12.85 \mathrm{~b}$ & $64.51 \mathrm{ab}$ & $0.0025 \mathrm{~b}$ & $0.0059 \mathrm{c}$ \\
\hline $40(1 / 3+2 / 3)$ & 124.3 & $103.33 \mathrm{c}$ & $336.17 \mathrm{~b}$ & $25016 \mathrm{~b}$ & $2.49 \mathrm{~b}$ & $21.08 \mathrm{~b}$ & $14.02 \mathrm{ab}$ & $64.90 \mathrm{ab}$ & $0.0026 \mathrm{ab}$ & $0.0068 \mathrm{c}$ \\
\hline $80(1 / 2+1 / 2)$ & 124.4 & $107.55 \mathrm{~b}$ & $371.58 \mathrm{a}$ & $33340 \mathrm{a}$ & $3.25 \mathrm{a}$ & $25.48 \mathrm{a}$ & $14.90 \mathrm{a} \mathrm{b}$ & $67.18 \mathrm{a}$ & $0.0027 \mathrm{a}$ & $0.0084 \mathrm{~b}$ \\
\hline $80(1 / 3+2 / 3)$ & 124.0 & $111.66 \mathrm{a}$ & $368.17 \mathrm{a}$ & $35791 \mathrm{a}$ & $3.57 \mathrm{a}$ & $25.45 \mathrm{a}$ & $16.03 \mathrm{a}$ & $65.77 \mathrm{a} \mathrm{b}$ & $0.0027 \mathrm{a}$ & $0.0099 \mathrm{a}$ \\
\hline & \multicolumn{10}{|c|}{ Talkef location } \\
\hline Zero & $124.6 \mathrm{~b}$ & $101.50 \mathrm{c}$ & $460.50 \mathrm{~b}$ & $56939 \mathrm{~b}$ & $5.66 \mathrm{~b}$ & $29.86 \mathrm{c}$ & $14.05 \mathrm{~b}$ & 69.86 & 0.0019 & 0.0112 \\
\hline $40(1 / 2+1 / 2)$ & $124.9 \mathrm{~b}$ & $106.08 \mathrm{bc}$ & $474.58 \mathrm{~b}$ & $56217 \mathrm{~b}$ & $5.57 \mathrm{~b}$ & $31.07 \mathrm{bc}$ & $13.47 \mathrm{~b}$ & 75.33 & 0.0021 & 0.0118 \\
\hline $40(1 / 3+2 / 3)$ & $125.0 \mathrm{ab}$ & $110.58 \mathrm{ab}$ & $492.33 \mathrm{~b}$ & $63820 a \mathrm{~b}$ & $6.34 \mathrm{ab}$ & $\begin{array}{c}33.90 \\
\text { abc }\end{array}$ & $14.09 \mathrm{~b}$ & 76.06 & 0.0020 & 0.0132 \\
\hline $80(1 / 2+1 / 2)$ & $125.7 \mathrm{a}$ & $113.91 \mathrm{a}$ & $506.67 \mathrm{ab}$ & $72688 \mathrm{a}$ & $7.23 \mathrm{a}$ & $37.81 \mathrm{a}$ & $13.58 \mathrm{~b}$ & 71.44 & 0.0020 & 0.0147 \\
\hline $80(1 / 3+2 / 3)$ & $125.7 \mathrm{a}$ & $113.58 \mathrm{a}$ & $556.75 \mathrm{a}$ & $65241 a b$ & $6.50 \mathrm{ab}$ & $36.72 \mathrm{ab}$ & $15.54 \mathrm{a}$ & 70.79 & 0.0021 & 0.0137 \\
\hline
\end{tabular}

The numbers bearing the same letter do not differ significantly at the probability level (5\%) 
Table (4): The effect of Polymer gel on the growth traits of the experiment location (Al-Hamdaniya and Talkef). AL- Hamdaniya location.

\begin{tabular}{|c|c|c|c|c|c|c|c|c|c|c|}
\hline $\begin{array}{l}\text { Growth traits } \\
\text { Polymer } \\
\text { gel }\end{array}$ & $\begin{array}{c}\text { No. of days } \\
\text { until } \\
\text { beginning } \\
\text { of flowering }\end{array}$ & $\begin{array}{l}\text { Plant } \\
\text { height } \\
(\mathrm{cm})\end{array}$ & $\begin{array}{l}\text { No.tillars } \\
\left(\mathrm{m}^{2}\right)\end{array}$ & $\begin{array}{l}\text { leaf area } \\
\left(\mathrm{cm}^{2} \cdot \mathrm{m}^{-}\right. \\
2)\end{array}$ & $\begin{array}{c}\text { leaf area } \\
\text { index } \\
\left(\mathrm{cm}^{2}\right)\end{array}$ & $\begin{array}{c}\text { Flag leaf } \\
\text { area } \\
\left(\mathrm{cm}^{2}\right)\end{array}$ & $\begin{array}{l}\text { (CCI) } \\
\text { Spad }\end{array}$ & $\begin{array}{c}\text { Water } \\
\text { content } \% \text { of } \\
\text { flag leaf }\end{array}$ & $\begin{array}{l}\text { (N.A.R) } \\
\left(\mathrm{g} / \mathrm{cm}^{2} /\right. \\
\text { day })\end{array}$ & $\begin{array}{l}\text { C.G.R } \\
\left(\mathrm{g} / \mathrm{cm}^{2} /\right. \\
\text { day })\end{array}$ \\
\hline Zero & 124.6 & $101.86 \mathrm{c}$ & $321.73 \mathrm{~b}$ & $24524 \mathrm{~b}$ & $2.44 \mathrm{~b}$ & $17.92 \mathrm{~b}$ & $12.67 \mathrm{~b}$ & $58.15 \mathrm{~b}$ & $0.0022 \mathrm{~b}$ & $0.0059 \mathrm{~b}$ \\
\hline 80 & 123.8 & $104.60 \mathrm{~b}$ & $333.73 \mathrm{~b}$ & $26043 \mathrm{~b}$ & $2.59 \mathrm{~b}$ & $22.71 \mathrm{a}$ & $14.60 \mathrm{a}$ & $65.55 \mathrm{a}$ & $0.0022 \mathrm{ab}$ & $0.0067 \mathrm{ab}$ \\
\hline 160 & 123.8 & $\begin{array}{c}106.13 \mathrm{a} \\
\mathrm{b}\end{array}$ & $337.80 \mathrm{ab}$ & $30336 \mathrm{a}$ & 2.96 & $23.75 \mathrm{a}$ & $14.68 \mathrm{a}$ & $68.20 \mathrm{a}$ & $0.0029 \mathrm{a}$ & $0.0085 \mathrm{a}$ \\
\hline 240 & 123.9 & $106.35 \mathrm{a}$ & $355.40 \mathrm{a}$ & $29769 \mathrm{a}$ & $2.97 \mathrm{a}$ & $21.81 \mathrm{a}$ & $14.53 \mathrm{a}$ & $67.28 \mathrm{a}$ & $0.00253 \mathrm{ab}$ & $0.0074 \mathrm{ab}$ \\
\hline \multicolumn{11}{|l|}{ Talkef location } \\
\hline Zero & 125.2 & $106.00 \mathrm{c}$ & $473.53 \mathrm{~b}$ & $50678 \mathrm{~b}$ & $5.16 \mathrm{~b}$ & $28.23 \mathrm{~b}$ & $3.29 \mathrm{~b}$ & $67.36 \mathrm{c}$ & 0.0019 & $0.0102 \mathrm{~b}$ \\
\hline 80 & 125.3 & $108.06 \mathrm{~b}$ & $487.53 \mathrm{bc}$ & $64297 \mathrm{a}$ & $6.36 \mathrm{a}$ & $34.68 \mathrm{a}$ & $14.23 \mathrm{a}$ & $72.14 \mathrm{~b}$ & 0.0020 & $0.0128 \mathrm{a}$ \\
\hline 160 & 125.2 & $111.13 \mathrm{a}$ & $\begin{array}{c}506.13 \mathrm{a} \\
\mathrm{b}\end{array}$ & $69745 \mathrm{a}$ & $6.85 \mathrm{a}$ & $35.21 \mathrm{a}$ & $14.57 \mathrm{a}$ & $74.43 \mathrm{a} \mathrm{b}$ & 0.0021 & $0.0140 \mathrm{a}$ \\
\hline 240 & 125.1 & $111.33 \mathrm{a}$ & $525.47 \mathrm{a}$ & $67204 \mathrm{a}$ & $6.68 \mathrm{a}$ & $37.37 \mathrm{a}$ & $14.49 \mathrm{a}$ & $77.01 \mathrm{a}$ & 0.0022 & $0.0148 \mathrm{a}$ \\
\hline
\end{tabular}

The numbers bearing the same letter do not differ significantly at the probability level (5\%) 
Mesopotamia J. of Agric.

Vol. (49) No. (1) 2021
ISSN: 2224 - 9796 (Online) ISSN: 1815 - 316 X (Print)

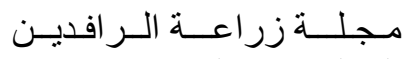

2021 المجلد (49) العدد (1)

Table (5): The effect of the interaction between nitrogenous fertilizer, application times, and polymer gel for the growth traits. AL- Hamdaniya location

\begin{tabular}{|c|c|c|c|c|c|c|c|c|c|c|c|}
\hline $\begin{array}{c}\text { Nitrogen } \\
\text { Fertilizer and } \\
\text { dates of } \\
\text { addition }\end{array}$ & $\begin{array}{l}\text { Polym } \\
\text { er gel }\end{array}$ & $\begin{array}{l}\text { No. days until } \\
\text { the beginning } \\
\text { of flowering }\end{array}$ & $\begin{array}{l}\text { Plant height } \\
(\mathrm{cm})\end{array}$ & $\begin{array}{l}\text { No. tillars / } \\
\mathrm{m}^{2}\end{array}$ & $\begin{array}{l}\text { leaf area } \\
\left(\mathrm{cm}^{2} \cdot \mathrm{m}^{-2}\right)\end{array}$ & $\begin{array}{c}\text { leaf area } \\
\text { index }\left(\mathrm{cm}^{2}\right)\end{array}$ & $\begin{array}{l}\text { Flag leaf } \\
\text { area }\left(\mathrm{cm}^{2}\right)\end{array}$ & (CCI) spad & $\begin{array}{c}\text { Water } \\
\text { content } \% \\
\text { of flag leaf }\end{array}$ & $\begin{array}{c}\text { (N.A.R) } \\
\left(\mathrm{g} / \mathrm{cm}^{2} / \text { day }\right)\end{array}$ & $\begin{array}{c}\text { C.G.R } \\
\text { (g / } \mathrm{cm}^{2} / \text { day) }\end{array}$ \\
\hline \multirow{4}{*}{ Zero } & Zero & $124.6 \mathrm{a} \mathrm{b}$ & $98.00 \mathrm{i}$ & $275.33 \mathrm{~g}$ & 18067 e & $1.79 \mathrm{~g}$ & $13.56 \mathrm{~h}$ & $11.65 \mathrm{~g}$ & $52.83 \mathrm{~d}$ & $0.0015 \mathrm{c}$ & $0.0028 \mathrm{f}$ \\
\hline & 80 & $124.0 \mathrm{a} \mathrm{b}$ & $99.33 \mathrm{~h} \mathrm{i}$ & $294.33 \mathrm{f}-\mathrm{g}$ & $20274 \mathrm{~d} \mathrm{e}$ & $2.02 \mathrm{e}-\mathrm{g}$ & $18.41 \mathrm{f}-\mathrm{g}$ & $12.85 \mathrm{f}-\mathrm{g}$ & $63.16 \mathrm{a}-\mathrm{d}$ & $0.0024 \mathrm{a}-\mathrm{c}$ & $0.0049 \mathrm{~d}-\mathrm{f}$ \\
\hline & 160 & $123.3 \mathrm{a} \mathrm{b}$ & $102.00 \mathrm{~g}-\mathrm{i}$ & $310.00 \mathrm{e}-\mathrm{g}$ & 24486 c-e & $2.44 \mathrm{~d}-\mathrm{g}$ & $17.45 \mathrm{~g} \mathrm{~h}$ & $14.74 \mathrm{a}-\mathrm{f}$ & $70.11 \mathrm{ab}$ & $0.0027 \mathrm{a} \mathrm{b}$ & $0.0058 \mathrm{c}-\mathrm{f}$ \\
\hline & 240 & $124.3 \mathrm{a} \mathrm{b}$ & $101.66 \mathrm{~g}-\mathrm{i}$ & $311.67 \mathrm{~d}-\mathrm{g}$ & 20979 d-e & $2.09 \mathrm{e}-\mathrm{g}$ & $17.84 \mathrm{~g} \mathrm{~h}$ & $12.86 \mathrm{fg}$ & $60.35 \mathrm{~b}-\mathrm{d}$ & $0.0027 \mathrm{a} \mathrm{b}$ & $0.0053 \mathrm{~d}-\mathrm{f}$ \\
\hline \multirow[t]{4}{*}{$40(1 / 2+1 / 2)$} & Zero & $125.3 \mathrm{a}$ & $99.00 \mathrm{~h} \mathrm{i}$ & $304.33 \mathrm{fg}$ & 20776 d-e & $2.06 \mathrm{e}-\mathrm{g}$ & $17.65 \mathrm{~g} \mathrm{~h}$ & $11.47 \mathrm{~g}$ & $62.14 \mathrm{a}-\mathrm{d}$ & $0.0020 \mathrm{~b} \mathrm{c}$ & 0.0040 e f \\
\hline & 80 & $123.6 \mathrm{a} \mathrm{b}$ & $101.66 \mathrm{~g}-\mathrm{i}$ & $299.00 \mathrm{f} \mathrm{g}$ & $18542 \mathrm{e}$ & $1.85 \mathrm{f}-\mathrm{g}$ & 19.32 e-h & $13.75 \mathrm{c}-\mathrm{g}$ & 65.99 a-d & $0.0023 \mathrm{a}-\mathrm{c}$ & 0.0044 e-f \\
\hline & 160 & $124.3 \mathrm{ab}$ & $102.66 \mathrm{~g} \mathrm{~h}$ & $304.00 \mathrm{f} \mathrm{g}$ & $26184 \mathrm{c}-\mathrm{e}$ & $2.61 \mathrm{~d}-\mathrm{g}$ & $19.49 \mathrm{~d}-\mathrm{h}$ & $12.97 \mathrm{fg}$ & $67.97 \mathrm{a}-\mathrm{c}$ & $0.0027 \mathrm{a} \mathrm{b}$ & $0.0073 \mathrm{a}-\mathrm{f}$ \\
\hline & 240 & $124.0 \mathrm{a} \mathrm{b}$ & $102.33 \mathrm{~g}-\mathrm{i}$ & $341.00 \mathrm{~b}-\mathrm{f}$ & $27468 \mathrm{c} \mathrm{d}$ & $2.74 \mathrm{~d}-\mathrm{f}$ & $19.53 \mathrm{~d}-\mathrm{h}$ & $13.21 \mathrm{e}-\mathrm{g}$ & $61.97 \mathrm{a}-\mathrm{d}$ & $0.0028 \mathrm{a} \mathrm{b}$ & 0.0079 a-e \\
\hline \multirow[t]{4}{*}{$40(1 / 3+2 / 3)$} & Zero & $124.6 \mathrm{a} \mathrm{b}$ & $99.00 \mathrm{~h} \mathrm{i}$ & $317.33 \mathrm{~d}-\mathrm{g}$ & $24055 \mathrm{c}-\mathrm{e}$ & $2.39 \mathrm{~d}-\mathrm{g}$ & $17.78 \mathrm{~g} \mathrm{~h}$ & $12.61 \mathrm{fg}$ & $60.46 \mathrm{~b}-\mathrm{d}$ & $0.0026 \mathrm{a}-\mathrm{c}$ & $0.0073 \mathrm{a}-\mathrm{f}$ \\
\hline & 80 & $124.0 \mathrm{a} \mathrm{b}$ & $103.33 \mathrm{f}-\mathrm{h}$ & 399.33 b-f & $26029 \mathrm{c}-\mathrm{d}$ & $2.59 \mathrm{~d}-\mathrm{g}$ & $22.11 \mathrm{~b}-\mathrm{g}$ & $13.70 \mathrm{~d}-\mathrm{g}$ & $60.70 \mathrm{~b}-\mathrm{d}$ & $0.0026 \mathrm{a}-\mathrm{c}$ & $0.0069 \mathrm{~b}-\mathrm{f}$ \\
\hline & 160 & $124.6 \mathrm{ab}$ & 105.00f-g & $331.00 \mathrm{c}-\mathrm{f}$ & $24756 \mathrm{c}-\mathrm{d}$ & $2.47 \mathrm{~d}-\mathrm{g}$ & $23.74 \mathrm{a}-\mathrm{g}$ & $14.38 \mathrm{~b}-\mathrm{f}$ & $66.66 \mathrm{a}-\mathrm{d}$ & $0.0027 \mathrm{a} \mathrm{b}$ & $0.0068 \mathrm{~b}-\mathrm{f}$ \\
\hline & 240 & $124.0 \mathrm{a} \mathrm{b}$ & 106.00f-g & 357.00 a-e & $25223 \mathrm{c}-\mathrm{e}$ & $2.51 \mathrm{~d}-\mathrm{g}$ & 20.43 c-h & 15.39 a-e & $71.78 \mathrm{ab}$ & $0.0024 \mathrm{a}-\mathrm{c}$ & $0.0060 \mathrm{c}-\mathrm{f}$ \\
\hline \multirow[t]{4}{*}{$80(1 / 2+1 / 2)$} & Zero & $124.0 \mathrm{a} \mathrm{b}$ & $104.00 \mathrm{f}-\mathrm{g}$ & $380.67 \mathrm{a} \mathrm{b}$ & $28013 \mathrm{c} \mathrm{d}$ & $2.79 \mathrm{c}-\mathrm{e}$ & $21.74 \mathrm{~b}-\mathrm{g}$ & $13.34 \mathrm{e}-\mathrm{g}$ & $60.23 \mathrm{~b}-\mathrm{d}$ & $0.0024 \mathrm{a}-\mathrm{c}$ & $0.0067 \mathrm{~b}-\mathrm{f}$ \\
\hline & 80 & $123.0 \mathrm{~b}$ & $108.00 \mathrm{c}-\mathrm{e}$ & 359.33 a-d & 29004 b-d & $2.88 \mathrm{~b}-\mathrm{e}$ & $26.43 \mathrm{a}-\mathrm{d}$ & $15.84 \mathrm{a}-\mathrm{d}$ & $70.62 \mathrm{ab}$ & $0.0031 \mathrm{a} \mathrm{b}$ & 0.0079 a-e \\
\hline & 160 & $123.6 \mathrm{a} \mathrm{b}$ & $107.33 c-f$ & $354.00 \mathrm{a}-\mathrm{e}$ & $39289 \mathrm{a}$ & $3.62 \mathrm{a}-\mathrm{c}$ & $27.69 \mathrm{ab}$ & $15.43 \mathrm{a}-\mathrm{e}$ & $62.29 \mathrm{a}-\mathrm{d}$ & $0.0033 \mathrm{a}$ & $0.011 \mathrm{a}$ \\
\hline & 240 & $123.0 \mathrm{~b}$ & 109.66a-d & $392.33 \mathrm{a}$ & $37053 \mathrm{a} \mathrm{b}$ & $3.70 \mathrm{a} \mathrm{b}$ & $26.07 \mathrm{a}-\mathrm{e}$ & 15.00 a-f & $75.60 \mathrm{a}$ & $0.0019 \mathrm{~b} \mathrm{c}$ & 0.0073 a-f \\
\hline \multirow[t]{4}{*}{$80(1 / 3+2 / 3)$} & Zero & $124.3 \mathrm{ab}$ & $109.33 \mathrm{c}-\mathrm{d}$ & $331.00 \mathrm{~d}-\mathrm{f}$ & 31710 a-c & $3.16 \mathrm{a}-\mathrm{d}$ & $18.89 \mathrm{f}-\mathrm{h}$ & $14.28 \mathrm{c}-\mathrm{f}$ & $55.13 \mathrm{c} \mathrm{d}$ & $0.0026 \mathrm{a}-\mathrm{c}$ & $0.0085 \mathrm{a}-\mathrm{e}$ \\
\hline & 80 & $124.3 \mathrm{a} \mathrm{b}$ & $110.66 \mathrm{a}-\mathrm{c}$ & $76.67 \mathrm{a}-\mathrm{c}$ & $36364 a-b$ & $3.63 \mathrm{a}-\mathrm{c}$ & 28.29 a-c & $16.87 \mathrm{a}$ & $67.27 \mathrm{a}-\mathrm{c}$ & $0.0027 \mathrm{a} \mathrm{b}$ & $0.0096 \mathrm{a}-\mathrm{d}$ \\
\hline & 160 & $123.3 \mathrm{a} \mathrm{b}$ & $113.66 \mathrm{a}$ & $390.00 \mathrm{a}$ & $36964 \mathrm{ab}$ & $3.69 \mathrm{ab}$ & $30.40 \mathrm{a}$ & $16.79 \mathrm{a} \mathrm{b}$ & $73.98 \mathrm{ab}$ & $0.0029 \mathrm{a} \mathrm{b}$ & $0.0111 \mathrm{ab}$ \\
\hline & 240 & $124.3 \mathrm{a} \mathrm{b}$ & $113.00 \mathrm{a} \mathrm{b}$ & $375.00 \mathrm{a}-\mathrm{c}$ & 38125 a & $3.80 \mathrm{a}$ & $25.20 a-f$ & $16.19 a-c$ & $66.71 \mathrm{a}-\mathrm{d}$ & $0.0027 \mathrm{a} \mathrm{b}$ & $0.0102 \mathrm{a}-\mathrm{c}$ \\
\hline
\end{tabular}

The numbers bearing the same letter do not differ significantly at the probability level (5\%) 
Mesopotamia J. of Agric.

Vol. (49) No. (1) 2021
ISSN: 2224 - 9796 (Online)

ISSN: 1815 - 316 X (Print)

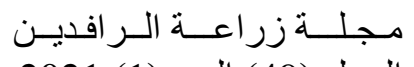

المجلد (49) العدد (1) 2021

Table (6): The effect of the interaction between nitrogenous fertilizer, application times, and polymer gel for the growth traits of Talkef location.

\begin{tabular}{|c|c|c|c|c|c|c|c|c|c|c|c|}
\hline $\begin{array}{l}\text { Nitrogen } \\
\text { Fertilizer and } \\
\text { dates of } \\
\text { addition }\end{array}$ & $\begin{array}{l}\text { Polym } \\
\text { er gel }\end{array}$ & $\begin{array}{l}\text { No . days } \\
\text { until the } \\
\text { beginning of } \\
\text { flowering }\end{array}$ & $\begin{array}{l}\text { Plant height } \\
\text { (cm) }\end{array}$ & $\begin{array}{c}\text { No.tillars / } \\
\mathrm{m}^{2}\end{array}$ & $\begin{array}{l}\text { leaf area } \\
\left(\mathrm{cm}^{2} \cdot \mathrm{m}^{-2}\right)\end{array}$ & $\begin{array}{c}\text { leaf area } \\
\text { index }\left(\mathrm{cm}^{2}\right)\end{array}$ & $\begin{array}{c}\text { Flag leaf } \\
\text { area }\left(\mathrm{cm}^{2}\right)\end{array}$ & (CCI)spad & $\begin{array}{c}\text { Water } \\
\text { content } \% \\
\text { of flag leaf }\end{array}$ & $\begin{array}{c}\text { (N.A.R) } \\
\left(\mathrm{g} / \mathrm{cm}^{2} /\right. \\
\text { day) }\end{array}$ & $\begin{array}{c}\text { C.G.R } \\
(\mathrm{g} / \mathrm{cm} 2 / \text { day })\end{array}$ \\
\hline \multirow{4}{*}{ Zero } & Zero & $124.33 \mathrm{~b} \mathrm{c}$ & $96.66 \mathrm{~g}$ & $423.67 \mathrm{f}$ & $43434 \mathrm{f}$ & $4.30 \mathrm{e}$ & $22.52 \mathrm{f}$ & $11.44 \mathrm{~h}$ & $65.64 \mathrm{f}-\mathrm{g}$ & 0.0018 & $0.0079 \mathrm{~d}$ \\
\hline & 80 & $125.00 \mathrm{ab}$ & $101.66 \mathrm{f}$ & $438.00 \mathrm{e} \mathrm{f}$ & $54003 \mathrm{~d}-\mathrm{f}$ & $5.36 \mathrm{c}-\mathrm{d}$ & $29.45 \mathrm{~d}-\mathrm{f}$ & $14.16 \mathrm{~d}-\mathrm{f}$ & $71.79 \mathrm{c}-\mathrm{f}$ & 0.0018 & $0.0100 \mathrm{a}-\mathrm{d}$ \\
\hline & 160 & $125.33 \mathrm{ab}$ & 106.00 e f & $476.00 \mathrm{~d}-\mathrm{f}$ & 73456 a-c & $7.36 \mathrm{a}-\mathrm{c}$ & $30.28 \mathrm{c}-\mathrm{e}$ & $15.34 \mathrm{a}-\mathrm{c}$ & $70.11 \mathrm{~d}-\mathrm{g}$ & 0.0019 & $0.0143 \mathrm{a}-\mathrm{c}$ \\
\hline & 240 & $124.00 \mathrm{c}$ & $101.66 \mathrm{f}$ & $504.33 \mathrm{~b}-\mathrm{d}$ & $56862 \mathrm{c}-\mathrm{f}$ & $5.63 \mathrm{~b}-\mathrm{e}$ & $37.21 \mathrm{a}-\mathrm{d}$ & $15.26 \mathrm{a}-\mathrm{c}$ & $71.90 \mathrm{c}-\mathrm{e}$ & 0.0022 & $0.0127 \mathrm{a}-\mathrm{d}$ \\
\hline \multirow[t]{4}{*}{$40(1 / 2+1 / 2)$} & Zero & $125.00 \mathrm{ab}$ & $101.66 \mathrm{f}$ & $423.67 \mathrm{f}$ & $42601 \mathrm{f}$ & $4.23 \mathrm{e}$ & $22.73 \mathrm{f}$ & $13.66 \mathrm{fg}$ & $70.36 \mathrm{~d}-\mathrm{g}$ & 0.0020 & $0.0087 \mathrm{c}-\mathrm{d}$ \\
\hline & 80 & $124.33 \mathrm{~b} \mathrm{c}$ & $106.00 \mathrm{ef}$ & $478.00 \mathrm{~d}-\mathrm{f}$ & $57057 \mathrm{c}-\mathrm{f}$ & $5.66 \mathrm{~b}-\mathrm{e}$ & 33.49 b-e & $13.70 \mathrm{e}-\mathrm{g}$ & $70.47 \mathrm{~d}-\mathrm{g}$ & 0.0021 & $0.0124 \mathrm{a}-\mathrm{d}$ \\
\hline & 160 & $125.00 \mathrm{a}-\mathrm{c}$ & $107.33 \mathrm{~d} \mathrm{e}$ & 495.67 b-e & 59357 b-f & $5.86 \mathrm{~b}-\mathrm{e}$ & $36.38 \mathrm{a}-\mathrm{d}$ & $13.35 \mathrm{fg}$ & $78.05 \mathrm{a}-\mathrm{c}$ & 0.0023 & $0.0118 \mathrm{a}-\mathrm{d}$ \\
\hline & 240 & $125.33 \mathrm{a}-\mathrm{c}$ & $109.33 \mathrm{c}-\mathrm{e}$ & $490.00 \mathrm{c}-\mathrm{e}$ & $65853 \mathrm{~b}-\mathrm{e}$ & $6.53 \mathrm{a}-\mathrm{c}$ & $31.70 \mathrm{~b}-\mathrm{e}$ & $13.16 \mathrm{~g}$ & $82.45 \mathrm{a}$ & 0.0022 & $0.0143 \mathrm{a}-\mathrm{c}$ \\
\hline \multirow[t]{4}{*}{$40(1 / 3+2 / 3)$} & Zero & $124.00 \mathrm{c}$ & 109.66 c-e & $509.00 \mathrm{~b}-\mathrm{d}$ & 50963 e-f & $5.03 \mathrm{de}$ & 24.96 e f & $13.29 \mathrm{fg}$ & $70.35 \mathrm{~d}-\mathrm{g}$ & 0.0018 & $0.0096 \mathrm{~b}-\mathrm{d}$ \\
\hline & 80 & $125.66 \mathrm{ab}$ & $109.66 \mathrm{c}-\mathrm{e}$ & $490.33 \mathrm{c}-\mathrm{e}$ & 67107 b-e & $6.70 \mathrm{a}-\mathrm{d}$ & $33.97 \mathrm{a}-\mathrm{d}$ & $14.53 \mathrm{c}-\mathrm{e}$ & $74.47 \mathrm{~b}-\mathrm{d}$ & 0.0018 & $0.0143 \mathrm{a}-\mathrm{c}$ \\
\hline & 160 & $125.66 \mathrm{ab}$ & $109.66 \mathrm{c}-\mathrm{e}$ & $478.88 \mathrm{~d}-\mathrm{f}$ & $64571 \mathrm{~b}-\mathrm{e}$ & $6.43 \mathrm{a}-\mathrm{d}$ & $38.88 \mathrm{a}-\mathrm{c}$ & $14.45 \mathrm{c}-\mathrm{e}$ & $79.68 \mathrm{ab}$ & 0.0020 & $0.0130 \mathrm{a}-\mathrm{d}$ \\
\hline & 240 & $125.00 \mathrm{a}-\mathrm{c}$ & $112.33 \mathrm{bc}$ & $491.67 \mathrm{~b}-\mathrm{e}$ & 72639 a-c & $7.20 \mathrm{a}-\mathrm{c}$ & $37.80 \mathrm{a}-\mathrm{d}$ & $14.10 \mathrm{~d}-\mathrm{g}$ & $79.75 \mathrm{ab}$ & 0.0021 & $0.0160 \mathrm{a}$ \\
\hline \multirow[t]{4}{*}{$80(1 / 2+1 / 2)$} & Zero & $126.33 \mathrm{a}$ & $110.00 \mathrm{c}-\mathrm{e}$ & $470.33 \mathrm{~d}-\mathrm{e}$ & $58537 \mathrm{c}-\mathrm{f}$ & $6.30 \mathrm{a}-\mathrm{d}$ & $36.04 \mathrm{a}-\mathrm{d}$ & $13.39 \mathrm{~g}-\mathrm{f}$ & $63.55 \mathrm{~g}$ & 0.0020 & $0.0128 \mathrm{a}-\mathrm{d}$ \\
\hline & 80 & $125.66 \mathrm{ab}$ & 110.66 c-e & $479.00 \mathrm{~d}-\mathrm{f}$ & 71149 a-d & $7.06 \mathrm{a}-\mathrm{d}$ & $40.19 \mathrm{a} \mathrm{b}$ & $13.22 \mathrm{fg}$ & $14.23 \mathrm{~b}-\mathrm{e}$ & 0.0020 & $0.0144 \mathrm{a}-\mathrm{c}$ \\
\hline & 160 & $125.00 \mathrm{a}-\mathrm{c}$ & $116.66 \mathrm{ab}$ & $530.67 \mathrm{~b}-\mathrm{d}$ & $84560 \mathrm{a}$ & $7.93 \mathrm{a}$ & $37.49 \mathrm{a}-\mathrm{d}$ & $13.80 \mathrm{~d}-\mathrm{g}$ & $72.59 \mathrm{c}-\mathrm{f}$ & 0.0019 & $0.0157 \mathrm{a}$ \\
\hline & 240 & $126.00 \mathrm{a}$ & $118.33 \mathrm{a}$ & $546.67 \mathrm{a}-\mathrm{c}$ & $76506 \mathrm{ab}$ & $7.63 \mathrm{ab}$ & $37.50 \mathrm{a}-\mathrm{d}$ & $13.91 \mathrm{~d}-\mathrm{g}$ & $76.41 \mathrm{a}-\mathrm{d}$ & 0.0021 & $0.0159 \mathrm{a}$ \\
\hline \multirow[t]{4}{*}{$80(1 / 3+2 / 3)$} & Zero & $126.33 \mathrm{a}$ & $112.00 \mathrm{~b}-\mathrm{d}$ & $530.00 \mathrm{~b}-\mathrm{d}$ & $57857 \mathrm{c}-\mathrm{f}$ & $5.93 \mathrm{a}-\mathrm{e}$ & $34.90 \mathrm{a}-\mathrm{d}$ & $14.69 \mathrm{~b}-\mathrm{d}$ & $66.90 \mathrm{e}-\mathrm{g}$ & 0.0020 & $0.0120 \mathrm{a}-\mathrm{d}$ \\
\hline & 80 & $126.00 \mathrm{a}$ & $112.33 \mathrm{~b}-\mathrm{d}$ & $552.33 \mathrm{ab}$ & 72169 a-c & $7.00 \mathrm{a}-\mathrm{d}$ & $36.29 \mathrm{a}-\mathrm{d}$ & $15.55 \mathrm{ab}$ & $70.73 \mathrm{~d}-\mathrm{f}$ & 0.0020 & 0.0127 a-d \\
\hline & 160 & $125.33 \mathrm{a}-\mathrm{c}$ & $116.00 \mathrm{a} \mathrm{b}$ & $550.00 \mathrm{a}-\mathrm{c}$ & $66781 \mathrm{~b}-\mathrm{e}$ & $6.66 \mathrm{a}-\mathrm{d}$ & $33.03 \mathrm{~b}-\mathrm{e}$ & $15.91 \mathrm{a}$ & $71.70 \mathrm{c}-\mathrm{f}$ & 0.0022 & $0.0157 \mathrm{ab}$ \\
\hline & 240 & $125.33 \mathrm{a}-\mathrm{c}$ & $114.00 \mathrm{a}-\mathrm{c}$ & $594.67 \mathrm{a}$ & $64158 \mathrm{~b}-\mathrm{e}$ & $6.40 \mathrm{a}-\mathrm{d}$ & $42.66 \mathrm{a}$ & $16.03 \mathrm{a}$ & $74.55 \mathrm{~b}-\mathrm{d}$ & 0.0023 & $0.0150 \mathrm{a} \mathrm{b}$ \\
\hline
\end{tabular}

The numbers bearing the same letter do not differ significantly at the probability level (5\%) 


\section{التاثير الفسيولوجي للسماد النتروجيني ومواعيد اضافته والهلام المائي على صفات}

Triticum aestivum L . النمو لمحصول حنطة الخبز

$$
\begin{aligned}
& \text { صالح محمد ابراهيم الجبوري1 } \quad \text { امجد ذنون خليل العبار } \\
& \text { (1) قسم المحاصيل الحقلية / كلية الزراعة والغابات / جامعة الموصل / العراق } \\
& \text { (2) قسم الانتاج النباتي / مديرية زراعة نينوى/ وزارة الزراعة /العراق }
\end{aligned}
$$

E:mail Salhmcbraheem@Yahoo.com

\section{الخلاصة}

نفذت التجربة الحقلية خلال الموسم الزراعي الثتوي 2019 - 2020 في موقعين (الحمدانية ، تلكيف) لدراسة تاثير السماد النتروجيني ومواعيد اضافته والهلام المائي في صفات النمو لمحصول حنطة الخبز Triticum aestivum L. وفق نظام الألواح المنثقة وبثلاث مكررات وتضمنت التجربة عاملين العامل الاول مستويات (RCBD) السماد النتروجيني ومواعيد اضافته وهي خمسة مستويات (صفر) معاملة المقارنة ، ( 40 كغمN/هـ : 112 عند الزراعة +112 بداية التفرعات) ، 80) ، (40 كغم/ه: 113 عند الزراعة +213 بداية التفرعات) كغم/هـ : 112 عند الزراعة +112 بداية التفرعات) ،(80 كغم/هـ : 113 عند الزراعة +213 بداية التثرعات) والعامل الثاني الهلام المائي باربع مستويات( 0 , 160, 80 ، 240 كغم/هـ) احتلت معاملات السماد النيتروجيني وموعد الاضافة الألواح الرئيسة في التجربة Main Plot واحتلت مستويات الهلام المائي القطع الثانوية Sub plots . تشير النتائج الى ان مستويات السماد النتروجيني ومواعيد اضافته حقت زيادة معنوية لأغلب صفات النمو ولكلا الموقعين ، كذلك مستويات الهلام المائي ادت الى زيادة معنوية في اغلب صفات النمو لموقعي الدراسة وحصلت استجابة معنوية للتداخل في جميع صفات النمو باستثناء عدد الايام حتى بداية التزهير لموقع الحمدانية ومعدل نمو المحصول لموقع تلكيف . الكلمات المفتاحية : التسميد النتروجيني ، الحنطة، مواعيد اضافته ، الهلام المائي تاريخ تسلم البحث: 17 / 11 / 2020، وقبوله :

\section{REFERENCES}

Abdelgawad, A.A.A., Noureldin, N.A., \& Faid, T.B. (1989) . Introduction to crop science principles of production ., Dar Al-arabiya for publishing and distribution.Cairo. $\mathrm{P}: 355$.

Agricultural Research Center. (2014). Cultivation of wheat in new lands republic of Egypt, Ministry of Agriculture, Agricultural Research Center, publication, No. 1333. P: 32.

Agricultural Statistics Directorate. (2019). Wheat and Barley production, republic of Iraq, Ministry of Planning, Central Bureau of Statistics. P:119 
Alamy, A. (2015). Analysis of the resistance of durum wheat (Triticam turgdam var duram L) to end-stage biological stresses, (Doctoral dissertation University in Setif). 222 .

Al-rawi,K.M.and A.A.I.Khalaf-Allah (2000). Design and analysis of agricultural experiments., ministry of higher education and scientific research, Dar Ibn AL-Atheer for printiong and publishing at the University of Mosul 488.

Antar, S.H. and Al-Wakaa A.H. (2017). Statistical analysis of agricultural experiences using SAS software, Dar of national books and documents in Baghdad. P: 469.

Duncan, D.D (1955) . Multiple range and multiple,F-Test biometrics,.11(1): 4042.

El-Hardy,O.A. AEl-Kade,A., \& Shafi,A. M. (2009). Physio-bio-chemical properties of the sandy soil conditioned with acrylamide hydrogels after cucumber plantation. Australian Journal Basic Applied Science, 3 ( 31), $45-51$

Grabinski, .J. \& Wyzinnska,M.,(2018).The effect of super absorbent polemer on yielding of winter wheat (Triticum aestivum L.)) of Soil Science and Plant Cultivation - State Research Institute, Poland, 10, (24), 55 - 61 .

Hunt,R.(1982). Plant growth curves:the functional approach to plant growth analysis. London , P:248.

Jassim, H.I. (2018) . Wheat production in Iraq for the 2016-2017 Agricultural Season. Ministry of Agriculture, Inspector General's Office, extension leaflet, P: 1-15.

Jion,Y.Shi.J.G,Ma.Yin,Dong.P.E \& Yon.Y.D (2017) . Super absorbent polymer properties and concentration effects on water retention ander drying conditions. Journal of Soil Science , 2 (81) , 889-901.

Khalil, N. A. , Abdullah,M., Shafiq,M.M. \&. Azim W.A (2015). Cereals and pulses cops., Cairo. $\mathrm{P}: 340$.

Muhammad,F.F. , Al-Shujairi,Z.K and.Abdullah.H.I. (2016). Principles of Field Crops, (Ministry of Higher Education and Scientific Research), University of Baghdad, P: 1-80.

Thomas, H. (1975). The grown response to weather of stimulated vegetative swards of a single genotype of lolium perenne . Journal. Agriculture Science. Cam., 2 (84) : $330-343$. 